IRYNA GRIDINA,

Mariupol State University (Mariupol, Ukraine)

e-mail: ingreedina@gmail.com, ORCID 0000-0002-3398-7708

MARYNA KASYANOVA,

Vasyl Stus Donetsk National University (Vinnytsia, Ukraine)

e-mail:mn.kasianova@gmail.com,ORCID 0000-0002-4681-1664

\title{
RUSSIA'S MIGRATION WEAPON AGAINST UKRAINE: A SOCIO-CULTURAL DIMENSION
}

The article is devoted to non-military and non-lethal means and instruments of the war of the Russian Federation against Ukraine, which, in combination with conventional weapons, kills both combatants and civilians, destroys housing, infrastructure, generates, another powerful weapon against the object of aggression, which is migration that has a large and long-lasting "zone" of defeat. Defining the characteristics that turn migration into a tool of hybrid warfare is an acute problem in the face of our country's hybrid aggression of the Russian Federation. Finding adequate measures to eliminate the devastating effects of migration processes both inside and outside Ukraine nowadays, furthermore, perhaps, much more important for the future, is one of the national policy priorities, the key to national security. The migration consequences of the Russian-Ukrainian war are analyzed, which should be regarded as pre-planned means of conducting a hybrid war. The article focuses on the hidden and artificially disguised sociocultural aspects of the defeat of migrant weapons, such as artificial prohibition, restrictions, targeted movement of population from temporarily occupied areas of Donetsk and Luhansk regions. It is concluded that the concealment of socio-cultural defeat creates the effect of a slow-motion explosion, which can detonate at any moment and be used as a time mechanism in the hands of the aggressor in political, information, educational, mental spaces: loosening of social unity, creating agents of influence of "Russian peace", the introduction of intolerance and socio-regional xenophobia, the transformation of temporarily occupied territories into an educational and intellectual ghetto. The possibility and necessity of finding countermeasures to migratory weapons located in the same plane in which the areas of damage are created should be noted, to act adequately to eliminate the consequences and prevent recurrence.

Key words: hybrid war; migration; migration weapons; temporarily occupied territories of Donetsk and Luhansk regions.

\section{Introduction}

The classic war, which Clausewitz writes about, has acquired (under the current conditions) such specific features that experts (in particular the military ones) note about its new plane and nature (Vedeneev, 2019), which is defined by the concept of hybridity. It is believed that war is such a socio-political phenomenon that not only rapidly develops, but also significantly outstrips the developed forms as opposed to peaceful relations (Serebryannikov, 1998: 6) But we join the opinion of those researchers who believe that although war changes its characteristics in different circumstances, no matter how they appear, will remain unchangeable, a war is still the war and its essence has not changed: "However, as Clausewitz stated nearly two centuries ago, although war changes its characteristics in various circumstances, in whatever way it manifests itself, war is still war. War in the twenty-first century has been and will remain a complex phenomenon, but its essence has not and will not change" (Mansoor, 2012: 1). However, the change in the characteristics of modern war is interdependent with the fundamental changes in the field of improvement, invention, modification, and in some cases the replacement of tools and instruments of the war. In fact, that is why the modern war was called "hybrid" because of the variety of non-lethal means. In the Russian scientific discourse there is even a concept - the "non-lethal war", which is defined as violence, and aimed at the social death of the enemy without his physical elimination (International Academy of Social Technologies) (Yunatskevich, 2016).

It is not by chance that the concept of "non-lethal war" is so actively investigated in Russia, whose open aggression against Ukraine in 2014 was one stage of a hybrid war against Ukraine, which began almost immediately after the sovereignty was acquired in 1991. A powerful component of Russia's hybrid war against Ukraine is non-military and non-lethal means and instruments: economic, diplomatic, information ones, etc. Combined with conventional weapons that kill both combatants and civilians, destroys housing, infrastructure, gives rise to another powerful weapon against the object of aggression is a migration that has a large and longlasting impact "zone".

Defining the characteristics that turn the migration into 
a tool of hybrid warfare is an acute problem in the face of our country's standoff to a hybrid aggression of the Russian Federation. Finding the adequate measures to eliminate the devastating effects of migration processes both inside and outside Ukraine nowadays, furthermore, perhaps, much more important for the future is one of the national policy priorities, the key to the national security.

In view of the abovementioned, the purpose of this study is to identify those qualitative characteristics of migration processes that, under certain conditions, can turn into a hybrid war instrument. With their own experience of being internally displaced persons, the authors focused on the hidden and artificially disguised sociocultural aspects of the affection.

The theoretical and methodological principles of the study used modern concepts of hybrid war (Mansoor, 2012; Horbulin (ed.), 2017), and migration as weapons of mass destruction (Kelly M. Greenhill), methods of analogy and extrapolation, including observations, interviews and conversations, analysis of regulatory documents, etc.

Hybrid war migration research is being actively pursued by domestic scientists, both in the general context and as special studies. The authors of the collective monograph dedicated to the World Hybrid War use the term "social instruments of the hybrid war" (Horbulin (ed.), 2017: 359), which caused significant losses to the social sphere of Ukraine, such as: expansion of poverty and deepening property stratification of the population, destruction of social infrastructure of annexed and occupied regions as well as closing the opportunities for the state to finance the social sphere, exacerbate social security problems of the security and defense sector, and physical and migration losses of the population. In fact, almost all of these losses are related to migration processes as a result of Russian aggression.

The domestic researcher, O.A. Malynovska, quite rightly observes that, for a long time, migration has not been covered by security discourse, since the view of security was predominantly in the sphere of foreign policy, whereas migration was regarded as a matter of internal affairs (Malynovska, 2018: 54). At the same time, the author gives examples of the use of refugees against their country of origin (Palestinians in Arab countries, Cubans in the USA), outlines the impact vectors of migration on economic (Ibid: 57), social (Ibid: 58), humanitarian issues, (Ibid: 59), security. In the article on the migration aspect of Russia's hybrid war against Ukraine, O.A. Malynovska and O.O. Kolomoiets expressly state that migration can be used as a tool of a hybrid war, which should lead for weakening of the enemy by bleeding and spending of resources for hosting and accommodation of migrants, solving related socio-economic, ethno-cultural and other problems. In support of this statement by demographic indicators, the authors note that the mass forced migration of the population caused by the aggression of Russia has become one of the most painful problems for Ukraine (Malynovska, Kolomoiets, 2017).

P.Kraliuk, Vice-Rector of the Ostroh Academy, also focuses on the migration aspect of hybrid war, an acute phase of which inevitably leads to increased migration flows, which in turn can be purposefully used to achieve certain goals in the hybrid wars (Kraliuk, 2016).

Ukrainian researcher L.A. Veselska also considers one of the main instruments of the hybrid war against Ukraine as forced mass migration of the inhabitants of the eastern regions of the Donbass (provoked and supported by the Russian authorities), emphasizing, as did O.A. Malinovska and O.O. Kolomoiets thus addressing the demographic crisis of the Russian Federation (Veselska, 2017).

Almost the first systematic study of the widespread but generally unrecognized instrument of state influence, which has been defined as Weapons of Mass Migration (Greenhill, 2010), has been made by Kelly M. Greenhill, a professor of political science at Tufts University and a research fellow at Harvard University's Kennedy School of Government. And in 2016, in the Military Review, a researcher published an article that could be called the sequel to her general monographic study entitled "Migration as a Weapon in Theory and in Practice" (Greenhill, 2016), as it continued to explore migration as a weapon, it focused on its practical application in the context of the EU migration crisis of 2015. "Indeed, as illustrated in detail in my 2010 book, Weapons of Mass Migration: Forced Displacement, Coercion and Foreign Policy, using displaced people as nonmilitary instruments of state-level coercion has long been a common feature of international politics.8 In fact, this frequently asymmetric brand of coercion-i.e., coercive engineered migration (CEM) - has been attempted at least seventy-five times since the advent of the 1951 Refugee Convention alone; that is at least one per year on average. 9 In that time, CEM has been undertaken by dozens of discrete state and non-state challengers against at least as many disparate targets and, by extension, against an equally large number of victimized groups of displaced people", - notes Kelly M. Greenhill (Greenhill, 2016: 24).

\section{Results and Discussion \\ Migration consequences of the Russian-Ukrainian} war

Occupation of the Crimea by Russia, the war in the east of Ukraine, and the temporary occupation of certain areas of Donetsk and Luhansk regions have caused largescale and unprecedented migration of the population both inside and outside the country. Almost two million Ukrainians were forced to leave their homes and migrate within their home country (about one and a half million people) and to other countries $(160,000$ people seeking refugee status were registered in Belarus, more than 600,000 in Russia, several thousand in Europe and the USA). Some of them have been granted refugee status, some have been registered as displaced persons, the vast majority of them are internally displaced persons, that is, displaced persons who have not left Ukraine's borders. Our country occupies the ninth place in the world by the number of internally displaced persons (Kolinko, 2019: 56-57).

Forced migration is fundamentally different from voluntary one, aimed at improving material and social status, in that, on the contrary, it causes loss of social status and destruction of the well-being of migrants. (Malynovska, analytical report). Usually, one of the main meanings of migration is resettlement, which is to permanently leave the former residence for one reason or another. In the Donbass, however, there was an escape from the war with the hope of a fast return, which led to the predominant spontaneous resettlement (mostly individual and family migration), to a lesser extent, organized displacement (those who were evacuated centrally with enterprises and organizations) (Kolinko, 2017: 367). The example of moving higher education institutions demonstrates the self-organization of evacuation, almost eliminating relevant government agencies from addressing this 
complex problem (Gridina, 2016). Part of the displaced persons left their country and went to other places of permanent or temporary residence. The rest people moved to other regions of Ukraine and received the status of "internally displaced persons" (hereinafter - IDPs).

An analytical report from the National Institute for Strategic Studies on the state of internal migration and temporarily displaced persons in Ukraine after the annexation of Crimea and the occupation of certain regions of Donetsk and Luhansk regions indicates that in 2015, most IDPs in the closest living areas had the intention of returning to abandoned homes. Such over-concentration of migrants has caused congestion on infrastructure, the labor market, and housing in the regions of the settlement (Malynovska, analytical report). But the further the war is delayed, the more IDPs focus on permanent residence in other regions of Ukraine. Thus, the aggression of the Russian Federation and the occupation of certain areas of Donetsk and Luhansk regions become a significant factor in the redistribution of the population over the territory of Ukraine in the long run. Despite state policy to protect the rights of IDPs (in November 2018, Ministry of Social Policy of Ukraine has set up a working group to elaborate the legal acts on the rights and freedoms of IDPs and other vulnerable population groups affected by armed conflict ${ }^{1}$, problems caused by forced migration continue to exceed the pace at which solutions are being found. Foreign and unfortunately domestic experience gives grounds to claim that the loss of sources of livelihood and work by IDPs creates a phenomenon of sudden poverty among the representatives of this group, and in the future - high level of long-term unemployment, poverty, social exclusion and orientation. State financial assistance as a major source of livelihood (Balakirieva (ed.), 2016: 4), which creates a huge economic burden on the belligerent country and social tensions in its society. There are more issues to be resolved regarding the process of locating forced migrants in new places of residence and integrating them into new communities, as well as the state and society's unwillingness to engage in large-scale internal migration, what exactly is taken into account when using such a tool as "migration weapons" by the aggressor. But apart from the purely economic and demographic negative effects caused by "migration weapons", there is a whole complex of socio-cultural aspects, at first glance, being not such existing ones, but equally dangerous.

\section{Socio-cultural "affection" of migration weapons}

Ukrainian researchers Malinovska O.A. and Kolomoiets O.O. believe that one of the preconditions of Russia's hybrid war against Ukraine was a permanent demographic crisis in the Russian Federation, which made the struggle for demographic resources one of the driving forces of aggression. Much of the Russian-speaking population of the Donbas falls under the concept of "compatriots" as understood in Russia. In addition to their linguistic and cultural affinities, migrants from the region have a high

\footnotetext{
1 Order of the Ministry of Social Policy of Ukraine No. 1739 of 20.11.2018. [Наказ Міністерства соціальної політики України № 1739 від 20.11.2018. Про утворення робочої групи Міністерства соціальної політики щодо опрацювання нормативноправових актів з питань забезпечення прав і свобод внутрішньо переміщених осіб та інших вразливих груп населення, постраждалих від збройного конфлікту]. Retrieved from: https://www.msp.gov.ua/files/norm_baza/1739.pdf (Accessed 20.09.2019).
}

level of education and professional competence, which favorably distinguishes them from Central Asian immigrants who constitute the majority of migrant workers in Russia (Malynovska, Kolomoiets, 2017: 82).

During the most active phase of the military confrontation, a significant number of residents of the eastern regions of Ukraine sought asylum in the territory of the Russian Federation, which was caused not only by territorial proximity, the presence of numerous personal connections, but also by a number of purposeful activities supported by advocacy tools (Ibid: 85 ). A widely publicized campaign for the protection of the Donbas population in the war against the "Kiev junta" was to rehabilitate the Russian Federation in the eyes of the international community, further channeling the exodus of forced migrants from occupied territories and frontier areas close to Russia. Further policy of the Russian Federation was aimed at the sewerage of the migration flow from the temporarily occupied territories, the gray zone, the frontier areas controlled by Ukraine: in 2017, the Russian government allowed Ukrainians to obtain Russian citizenship under a simplified procedure; in December 2018, Putin signed a law allowing permission to apply for Russian citizenship remotely, at the place of residence, in March 2019, amendments to the law "On Russian citizenship" came into force, under which the president of Russia can identify large groups of foreigners who have the right to apply for citizenship of the Russian Federation under the simplified procedure. Issuance of Russian passports under the simplified procedure to residents of Donetsk and Luhansk regions (they do not have internal registration), agitation within the "Russian compatriot" project to receive passports of Russian citizens by the residents of other regions of Ukraine actually creates a springboard for future invasion for the "protection ow the citizens". This option has already been tried in Georgia in 2008, when the mass receipt of Russian citizens' passports in Abkhazia and South Ossetia became a cover for the invasion under the slogan of protecting "Russian citizens" from "Georgian aggression".

Conversely, the spread of "Russia's space" in the temporarily occupied territories is served by the tacit process of resettlement of Russian citizens - first military men and then their families, arrival of Russian citizens to the region with the purpose of doing business, acquisition of real estate and property. It is not possible to speak about any quantitative characteristics of these processes, because, firstly, the Russian Federation hides the presence of its military units in the temporarily occupied territories, and the temporarily occupied territories also lost the information subjectivity of information due to lack of the legal standing. But the personal observations of the authors of the article give reason to argue, though not about the mass, but rather dangerous process of changing the ethnic stratification of the population of the region. Even in times of war and occupation, the industrial cities of Donetsk and Luhansk regions are attractive to Russian citizens from depressive regions of the Russian Federation. The "militaristic interest" of Russian newcomers is worsening the security situation in the temporarily occupied and adjacent areas of Donetsk and Luhansk regions, and in the future will significantly complicate the implementation of the peace process in these territories.

The complex processes of adaptation of IDPs in host communities, the associated social tensions, fueled by Russian propaganda, provoked or spontaneous exacerbation of the situation from the Ukrainian side can also 
be considered as a manifestation of migration weapons aimed at loosening Ukrainian society, continuation of the policy of regional split with the use of IDPs from the eastern regions.

In this context, the interesting classification of IDPs by the criterion of the degree of adaptation was proposed by the domestic researcher L. Chuprii (2018), identifying, among other things, the positive and negative sociocultural aspects of their interaction with local communities and the state.

Thus, "adaptables" are over 35 but under 60 , try to live in a new environment, rent housing, look for work, organize their business, move their business to a new place. Most of them are representatives of the upper class, people with higher education, more than a quarter, but less than a third. Their positive features are activity, in particular public, intellectual, and business constructive contributions to the settlement region. But such activity often drives them to leave Ukraine. In this way, not only the Donetsk and Luhansk regions have lost the most active or promising middle class, the intellectual elite, but gradually the state is also losing it.

Temporaries are people of all ages, but mostly over the age of 45 , unable to, and often reluctant to adapt, because they have the compulsive idea of returning home. The impossibility of its realization causes depression, exacerbation of post-traumatic syndrome, escape from reality. As a rule, these are former low-income civil servants, socially inactive and apolitical. They live mainly in places of social housing - dormitories, sanatoriums, hotels. There are about a quarter, but less than a half of them. The reluctance to adapt and the resulting marginalization create an economic and social burden on the host community, create a corresponding negative attitude towards IDPs, create a social rejection.

The "dependents" is the most distinctive category of passive and active divorced, retired, seasonal entrepreneurs - "grantees", which are combined by one strategy to earn on their status. The author considers that there is a half or more of these people of all IDPs. The dependents create that active and negative image of IDPs among host communities, but by their very existence, they support the activities of volunteer and community organizations. At the same time, they become the object of manipulation by the Russian Federation on violation of their rights, lack of concern on the part of the state.

It is possible to treat the classification proposed by L. Chupri in different ways, it is clear that it is rather conditional, and, for example, the authors personally know many exceptions to the proposed "types". However, the very presence in the scientific discourse of such a characteristic of IDPs is a manifestation of stereotyping and even stigmatization, even if it is a positive connotation. Social loosening is one of the effective tools of a hybrid war that the Russian Federation uses directly or indirectly.

Describing the problem of adaptation of IDPs in the concept of transgression, the domestic researcher M. Kolinko emphasizes the more appropriate and profound use of the term "transgressant", because in French it means "one who transcends the norms" (Kolinko, 2019: 368). Indeed, the situation of forced migration as a result of the Russian-Ukrainian war goes far beyond what Kelly M. Greenhill described, an expert in using the migration as a tool of blackmail, coercion, and the like. Just as Donbass is not a goal of war in the east of Ukraine, it is an instrument of a hybrid war of the Russian Federation against all
Ukraine with the strategic aim of including it in its sphere of influence as a colony, otherwise its decline to impede integration into Euro-Atlantic structures, so migration itself, provoked, supported and managed by the Kremlin's power, is a tool, a social weapon, for weakening and destroying the state.

As a result of the external aggression of the Russian Federation, creation of internal borders in Ukraine (by definition of M. Kolinko) transformed people into transgressors who cross not only barriers in the form of checkpoints, but also acquire essential transgressive characteristics (Kolinko, 2017: 372). Migrant transgressors are characterized by a dual identity (inseparation from a former cultural group with a simultaneous desire/unwillingness to be regarded as their host community), introducing one's own ideas about the home world into another culture (which may pose a potential danger to the host culture (Ibid: 374,377 ). In response, there has been discrimination against migrants by the host community (refusal to rent, employment, health care or other social services, etc.), in 2014-2017, there have been frequent instances of passive aggression - accusations of displaced persons in local problems, use of hate speech in mass media. Explanations to these phenomena (not justifications) should be sought in the fatigue of the presence of "others" who become potential (and in compelling circumstances, active ones) competitors for jobs, clients, education, etc.; the passive stance of "dependents" at the expense of taxes of other Ukrainian citizens is also condemned.

Paradoxically, but another powerful socio-cultural consequence of forced migration is its artificial prohibition or restriction, or purposeful containment. Existing obstacles to the exercise of IDPs' rights to freedom of movement (restrictions on the movement of civilians through the demarcation line and the prohibition of crossing the line of collision with public passenger transport were carried out in accordance with the Temporary Procedure for Control of the Movement of Persons through the Collision Line in Donetsk and Luhansk Oblast 2017), are now regulated by Law of Ukraine No. 2268 dated February 24, 2018 "On the Features of State Policy for Ensuring State Sovereignty of Ukraine in Temporarily Occupied Territories in Donetsk and Luhansk Regions") leads to a deepening separation between the inhabitants of the once united community, spreads moods of dissatisfaction, criticism of forced government policy, and so on. According to the information provided by the United Nations, an average of 1.1 million crossings of the demarcation line was recorded in 2018, which is an average of 38000 crossings per day. The number of intersections increased by $49 \%$ compared to the same period in 2017, when the number of intersections per day was $25,500^{2}$. Risks at checkpoints at the demarcation line: mine risk, danger of shelling during military exacerbations, long queues associated with this, frequent deaths at the checkpoint, restriction of goods transportation, requires the Ukrainian government to improve the conditions of crossing occasionally demarcate and equip the checkpoint with everything you need. But, seemingly improving the conditions of crossing the line of demarcation leads to the

${ }^{2}$ UN Information Brief [Svoboda peresuvannia cherez liniiu rozmezhuvannia na skhodi Ukrainy: informatsiina dovidka OON]. URL: http://www.un.org.ua/images/documents/4712/Briefing\%20Note\%20Advocacy\%20on\%20Social\%20Cohesion_ua.pdf (Accessed: 20.09.2019). 
spread of sentiment among the population, that the arrangement of the checkpoint indicates the reluctance of the authorities to end the war, the rumors about "making money on war, on blood" are being heated. In this way, the Kremlin's leadership, criticizing the Ukrainian government from all international tribunals for violations of human rights, including for free movement, declares Ukraine's reluctance to start a peace process. However, much worse conditions of crossing the checkpoint in the temporarily occupied territories are deliberately hidden.

Problems related to restriction of movement of residents of temporarily occupied territories of certain districts of Donetsk and Luhansk regions through the line of demarcation, prohibition of trips to Ukraine to certain categories of population (heads of enterprises and organizations, officials, civil servants, etc.) by occupation administration, refreshments, renovations, difficulties obtaining a Ukrainian passport and other identification documents creates hostages for them in their place of residence or in very limited areas of travel. Lack of international transport communication and limited domestic one are forcing residents of temporarily occupied areas to meet the needs for travel, recreation in Russia, Abkhazia, or to implement them through the Russian Federation. It is not difficult to guess that it is the Russian authorities that are encouraging these processes, trying to close the information and space circle for the inhabitants of the occupied territories, which, firstly, makes them "agents" of "Russia's space", and secondly, it will extremely complicate the processes of de-occupation of consciousness for the Ukrainian authorities.

Restricting the right to free movement of Ukrainian citizens who remained in the temporarily occupied areas of Donetsk and Luhansk regions deprived them of a number of state-guaranteed rights, including education, academic mobility. Deprived of the educational sector of the temporarily occupied regions of Donetsk and Luhansk regions of legal standing, taking over its financial and ideological content, the Russian Federation received a powerful tool of hybrid warfare. The complete transfer of both higher and secondary education into Russian standards, the continuous Russification of education, the elimination of the organizational elements and content of Ukrainian education serve to deepen the split of the once unified educational space, and thus rapidly complicate the mechanisms of returning occupied territories to the Ukrainian education system. Depriving the population of real and virtual mobility greatly simplifies the direct and systematic brainwashing by the Russian propaganda of the most conscious and active part of the population of the region - students and teachers through the implementation of Russian standards and educational programs, their obligatory attestation and retraining on the Russian intellectual product (inability to participate in foreign conferences other than Russian conferences, participate in grants, to be published in leading scientific journals, etc.). In fact, we are talking about the process of "enslavement" of the youth in the temporarily occupied territories by the RF. Having received previously unrecognized diplomas of education, young people doom themselves to the status of hostages of the occupied territories in the conditions of permanently increasing unemployment, or have the only alternative - to seek employment in the Russian Federation. The "educational abyss", which deepens with each passing year of war, creates a kind of intellectual ghetto in the occupied territories. RF, by funding and managing the educational simulacrum, receives its own agents of influence, brought up in a hostile civilization space (Gridina, Hedo, 2018).

\section{Conclusions}

The socio-cultural implications of using migration as a weapon in the hybrid war of Russia against Ukraine are closely intertwined with the economic, security, demographic, political aspects of mass and unprecedented domestic migration. They may not be as existent as economic bleeding and spending of resources on receiving and arranging migrants, but their concealment is one of the most important strategies of hybrid warfare: masking goals and actions, in particular by swapping concepts and real social objects, justification for war to protect imaginary or artificially created "compatriots", creation of conditions for forced restriction of movement or directing of migration flows to the desired way. The concealment of sociocultural defeat creates a slow-motion effect that can detonate at any moment and be used as a time mechanism in the hands of the aggressor in political, informational, educational, and mental spaces. Thus, the effect of the dehumanization of the attitude of political elites and the population towards IDPs is used to undermine social unity, instill intolerance and socio-regional xenophobia.

But as with any real weapon, the counter-measures can and should be found in the same plane in which the affected areas are created and acted upon to adequately address the consequences and prevent the recurrence. In the socio-cultural dimension, first of all, it should be transparency - not maintaining a semblance that the problem does not exist, because it is easier not to acknowledge mistakes in the regulation of the process at the state and local levels, but a detailed analysis of budgets and audit of losses to overcome and correct them. The cessation of any hate speech towards the forced refugees and displaced persons that goes beyond the respect of the rights and obligations of the citizen of Ukraine should be stopped. Establishment of state programs for employment, retraining, renewal and start-up of businesses in order not to create a taxpayer (not a fish, but a "fishing rod") for the immigrants. Information and explanatory work on the true goals and pitfalls of Russian passportization (today this is limited only by the fixation of this fact in the media and banners such as "get a Russian passport, invite the occupier home"). The protection of the rights and freedoms of civilians in the temporarily occupied territories in Donetsk and Luhansk regions are declared in the Law of Ukraine "On the Features of the State Policy on Securing the State Sovereignty of Ukraine in the Temporarily Occupied Territories in Donetsk and Luhansk regions" (Art. 6)., that more or less successfully implemented the first part of item 7 - providing access to educational establishments and mass media of Ukraine.

\section{REFERENCES}

Balakirieva, O. M. (ed.) (2016). Vymusheni pereselentsi ta pryimaiuchi hromady: uroky dlia efektyvnoi suspilnoi adaptatsii $y$ intehratsii. Kyiv: NAN Ukrainy, DU "In-t ekon. ta prohnozuv. NAN Ukrainy". 140 p. (In Ukrainian)

Chuprii, L. (2018). Adaptatsiia vymushenykh pereselentsiv zi Skhodu Ukrainy: stan i problemy. In: Rosiiska ahresiia proty Ukrainy: pravda i vyhadky, prychyny i naslidky. Kyiv: MP Lesia, pp. 370-385. (In Ukrainian)

Greenhill, Kelly M. (2016). Migration as a Weapon in Theory and in Practice. Military Review, 96. no. 6. (Nov-Dec): 23-36. 
Greenhill, Kelly M. (2010). Weapons of Mass Migration: Forced Displacement, Coercion, and Foreign Policy. Ithaca, NY: Cornell University Press, $360 \mathrm{p}$.

Gridina, I. M. and Hedo, A. V. (2018). Studentska akademichna mobilnist $v$ konteksti derzhavnykh interesiv ta natsionalnoi bezpeky. Internatsionalizatsiia vyshchoi osvity Ukrainy $v$ umovakh polikulturnoho svitovoho prostoru: stan, problemy, perspektyvy: mater. II mizhnar. nauk.-prakt. konf., m. Mariupol, 18-19 kvitnia 2018 r. Mariupol: MDU, pp. 156-158. (In Ukrainian)

Gridina, I. M. (2016). Osvitianskyi front viiny na Skhodi Ukrainy. Visnyk Mariupolskoho derzhavnoho universytetu. Seriia: istoriia, politolohiia. Issue 16: 199-208. Retrieved from http://www.irbisnbuv.gov.ua/cgi-bin/irbis_nbuv/cgiirbis_64.exe?I21DBN=LINK\&P21DBN=UJRN\&Z21ID $=\& S 21 R E F=10 \& S 21 C N R-=20 \& S 21 S T N=-$ 1\&S21FMT =ASP_meta\&C21COM=S\&2_S21P03=FILA=\&2_S21STR=Vmdu_ip_2016_16_27 (Accessed: 18.09.2019) (In Ukrainian)

Horbulin, V. P. (ed.) (2017). Svitova hibrydna viina: ukrainskyi front. Kyiv: Natsionalnyi instytut stratehichnykh doslidzhen. 496 p. (In Ukrainian)

Kolinko, M. (2017). Transhresiia povsiakdennosti: dosvid pereselennia $v$ umovakh hibrydnoi viiny na Donbasi. In: Hibrydna viina: in verbo et in praxi. Vinnytsia: Nilan-LTD: 363-379. (In Ukrainian)

Kolinko, M. (2019). Nomadism as a way of being of the immigrants and internally displaced persons. EUREKA: Social and Humanities, 2: 56-62. DOI: 10.21303/2504-5571.2019.00868

Kolinko, M. V. (2019). Mizhkulturna komunikatsiya: topolohichnyy vymir. Vinnytsya: TOV "TVORY", 344 p. (In Ukrainian)

Kraliuk, P. (2016, 05). Ukraina i Rosiia. Bizhentsi u hibrydnykh viinakh Kremlia. Website VOA, Inc. Retrieved from https:// ukrainian.voanews.com/a/ukraine-and-russia/3270226.html (Accessed: 20.09.2019). (In Ukrainian)

Malynovska, O. A. (2018). Mihratsiina polityka: hlobalnyi kontekst ta ukrainski realii. Kyiv: Natsionalnyi instytut stratehichnykh doslidzhen. 472 p. (In Ukrainian)

Malynovska, O. A. and Kolomoiets, O. O. (2017). Mihratsiinyi aspekt hibrydnoi viiny Rosii proty Ukrainy. Demohrafiia ta sotsialna ekonomika, 2 (30): 78-88. DOI: https://doi.org/10.15407/ dse2017.02.078 (In Ukrainian)

Malynovska, O. A. Vnutrishnia mihratsiia ta tymchasovo peremishchenni $v$ Ukraini $v$ umovakh politychnykh ta sotsialnoekonomichnykh zahroz: Analitical Report. Retrieved from http:// old2.niss.gov.ua/content/articles/files/vnutrishnya_migratsia45aa1.pdf (Accessed: 20.09.2019). (In Ukrainian)

Mansoor, Peter R. and Murray, W. (2012). Hybrid War in History. Hybrid Warfare: Fighting Complex Opponents from the Ancient World to the Present. Cambridge: Cambridge University Press: $1-18$.

Serebryannikov, V. V. (1998). Sotsiologiya voyny. Moscow: Os-89, 320 p. (In Russian)

Vedeneev, D. (2019). Vid Makiavelli do viin robotiv: hramatyka "hibrydnoi" viiny. Oboronno-promyslovyi kurier. 02.19. Retrieved from http://opk.com.ua/vid-makiavelli-do-viin-robotiv-hramat/ (In Ukrainian) (Accessed: 20.09.2019)

Veselska, L. A. (2017). Masova vymushena mihratsiia yak instrument vedennia hibrydnoi viiny. Menedzher, 3 (76): 108-117. Retrieved from http://dsum.edu.ua/wp-content/uploads/2015/11/ \%E2\%84\%96-3-76-2017.pdf (Accessed 17.08.2019) (In Ukrainian)

\section{LIST OF REFERENCES LINKS}

Вимушені переселенці та приймаючі громади: уроки для ефрективної суспільної адаптації й інтеграції: наукова доповідь / Балакірєва О. М. (ред.); НАН України, ДУ "Ін-т екон. та прогнозув. НАН України". К., 2016. 140 с.

Веденеев Д. Від Макіавеллі до війн роботів: граматика "гібридної" війни. Оборонно-промисловий кур'єр. 2019. 19 лю- того. URL: http://opk.com.ua/від-макіавеллі-до-війн-роботівграмат/ (дата звернення 20.09.2019).

Весельська Л. А. Масова вимушена міграція як інструмент ведення гібридної війни. Менеджер. 2017. №3 (76). C. 108-117. URL: http://dsum.edu.ua/wp-content/uploads/2015/ 11/\%E2\%84\%96-3-76-2017.pdf (дата звернення 17.08.2019).

Грідіна І. М., Гедьо А. В. Студентська академічна мобільність в контексті державних інтересів та національної безпеки. Інтернаціоналізація вищої освіти України в умовах полікультурного світового простору: стан, проблеми, перспективи: матер. II міжнар. наук.-практ. конф., м. Маріуполь, 18-19 квітня 2018 р. Маріуполь: МДУ, 2018. С. 156-158.

Грідіна І. М. Освітянський фронт війни на Сході України. Вісник Маріупольського державного університету. Серія: історія, політологія. Випуск 16. Маріуполь: МДУ, 2016. С. 199208. URL: http://www.irbis-nbuv.gov.ua/cgi-bin/irbis_nbuv/cgiirbis_64.exe?|21DBN=LINK\&P21DBN=UJRN\&Z21ID $=\& S 21 \overline{R E F}=10 \& S 21 \mathrm{CNR}-$ $=20 \& S 21 \mathrm{STN}=1 \& S 21 \mathrm{FMT}=A S P \_$meta\&C21COM=S\&2_S21P03=FILA=\&2_S21STR=Vmdu_ip_2016_16_27 (дата звернення 18.09.2019).

Колінько М. Трансгресія повсякденності: досвід переселення в умовах гібридної війни на Донбасі. Гібридна війна: in verbo et in praxi: монографрія / за заг. ред. проф. Р. О. Додонова. Вінниця: ТОВ "Нілан-ЛТД", 2017. С. 363-379.

Колінько М. В. Міжкультурна комунікація: топологічний вимір: монографрія. Вінниця: ТОВ "ТВОРИ", 2019. 344 с.

Кралюк П. Україна і Росія. Біженці у гібридних війнах Кремля. Вебсайт "Голос Америки". Блоги. 05.2016. URL: https:// ukrainian.voanews.com/a/ukraine-and-russia/3270226.html (дата звернення 20.09.2019).

Малиновська О.А.Коломоєць О. О. Міграційний аспект гібридної війни Росії проти України. Демографрія та соиіальна економіка. 2017. № 2 (30). C. 78-88. DOI: https://doi.org/10.15407/ dse2017.02.078

Малиновська О. А. Внутрішня міграція та тимчасово переміщені в Україні в умовах політичних та соціально-економічних загроз: аналітична записка URL: http://old2.niss.gov.ua/ content/articles/files/vnutrishnya_migratsia-45aa1.pdf (дата звернення 20.09.2019).

Малиновська О. А. Міграційна політика: глобальний контекст та українські реалії: монографрія. К.: НІСД, 2018. 472 с.

Світова гібридна війна: український фронт / Горбулін В. П. (ред.); Національний інститут стратегічних досліджень. К.: НІСД, 2017. 496 c. $320 \mathrm{c}$

Серебрянников В. В. Социология войны. М.: Ось-89, 1998.

Чупрій Л. Адаптація вимушених переселенців зі Сходу України: стан і проблеми. Російська агресія проти України: правда і вигадки, причини і наслідки. К.: МП Леся, 2018. C. $370-385$

Юнацкевич П. И. Концепция нелетальной войны и доктрина современной войны для государств-участников СНГ. URL: https://in.ast.social/300-kontseptsiya-neletalnoj-vojny-idoktrina-sovremennoj-vojny-dlya-gosudarstv-uchastnikovsng.html (дата звернення 20.09.2019).

Greenhill Kelly M. Migration as a Weapon in Theory and in Practice. Military Review. 2016. vol. 96. no. 6. (Nov-Dec). P. 23-36.

Greenhill Kelly M. Weapons of Mass Migration: Forced Displacement, Coercion, and Foreign Policy. Ithaca, NY: Cornell University Press, 2010. March. 360 p.

Kolinko M. Nomadism as a way of being of the immigrants and internally displaced persons. EUREKA: Social and Humanities. 2019. N. 2. P. 56-62. DOI: $10.21303 / 2504-5571.2019 .00868$

Peter R. Mansoor. Hybrid War in History. Hybrid Warfare: Fighting Complex Opponents from the Ancient World to the Present / ed. Williamson Murray and Peter R. Mansoor. Cambridge: Cambridge University Press, 2012. P. 1-18. 
Ірина Грідіна,

Маріупольський державний університет (м. Маріуполь, Украӥна)

e-mail: ingreedina@gmail.com,ORCID 0000-0002-3398-7708

Марина Касьянова,

Донецьький національний університет імені Василя Стуса (м. Вінниия, Україна)

e-mail: mn.kasianova@gmail.com, ORCID 0000-0002-4681-1664

\section{МІГРАЦІЙНА ЗБРОЯ РОСІЇПРОТИ УКРАЇНИ: СОЦІОКУЛЬТУРНИЙ ВИМІР}

Статтю присвячено невоєнним та нелетальним засобам та інструментам війни РФ проти України, які, у поєднанні зі звичайним озброєнням, призначеним для вбивства комбатантів і цивільного населення, руйнування житла, інфраструктури, породжують ще одну потужну зброю проти об'єкта агресії - міграційну, яка має великопросторову та довготривалу "зону" ураження. Визначення характеристик, які перетворюють міграцію на інструмент гібридної війни, є гостроактуальною проблемою в умовах протистояння нашої країни гібридній агресії РФ. Винайдення адекватних заходів ліквідації руйнівних наслідків міграційних процесів як усередині України, так і за їі межами у теперішній час, i, що мабуть більш важливо, у майбутньому є одним 3 першочергових завдань державної політики, запорукою національної безпеки. Аналізуються міграційні наслідки російсько-української війни, які варто розцінювати як заздалегідь сплановані засоби ведення гібридної війни. У статті акцентується увага на прихованих та штучно замаскованих соціокультурних аспектах ураження міграційної зброї, таких як штучні заборона, обмеження, цілеспрямоване переміщення населення 3 тимчасово окупованих районів Донецької та Луганської областей. Робиться висновок, що прихованість соціокультурного ураження створює ефект вибухівки уповільненої дії, яка може здетонувати у будь-який момент та використовуватися як часовий механізм у руках агресора в політичному, інформаційному, освітньому, ментальному просторах: розхитування суспільної єдності, створення агентів впливу "русского міра", насадження нетерпим ості та соціально-регіональної ксенофобії, перетворення тимчасово окупованих територій на освітянське та інтелектуальне гетто. Зазначається про можливості та необхідність віднайдення контрзаходів міграційній зброї, які знаходяться в тій самій площині, що й створені зони ураження, діяти адекватно на усунення наслідків та попередження рецидивів.

Ключові слова: гібридна війна; міграція; міграційна зброя; внутрішньо переміщені особи; тимчасово окуповані території Донецької і Луганської областей.

(C) Gridina Iryna, Kasyanova Maryna

Надійшла до редакції: 25.09.2019

Прийнята до друку: 14.10.2019 